\title{
PERANCANGAN SISTEM PEMANTAU KUALITAS AIR PADA BUDIDAYA IKAN AIR TAWAR
}

\author{
Kuat Indartono $^{1}$, Bagus Adhi Kusuma ${ }^{2}$, Agam Purusha Putra ${ }^{3}$ \\ 1,2,3) Program Studi Informatika, Fakultas Ilmu Komputer, Universitas Amikom Purwokerto \\ email : indartono@amikompurwokerto.ac.id ${ }^{1)}$, bagus@amikompurwokerto.ac.id ${ }^{2)}$, agamputra80@gmail.com ${ }^{3)}$
}

\begin{abstract}
Abstraksi
Melimpahnya sumberdaya air di Indonesia dapat dimanfaatkan sebagai budidaya ikan air tawar. Namun kekayaan sumberdaya air tersebut terkadang tidak dijaga oleh manusia sehingga kualitas air yang digunakan untuk budidaya ikan menjadi kurang baik atau bahkan di bawah standar. Misalnya pencemaran limbah yang sering terjadi saat ini tidak hanya dapat menyerang wilayah perkotaan namun juga pedesaan seperti adanya limbah rumah tangga. Selain itu pergantian musim penghujan dan kemarau, dan faktor yang lain seperti kebencanaan juga dapat menyebabkan perubahan kualitas air. Parameter kualitas air tidak hanya diukur dari segi pencemaran kandungan kimiawi, namun terdapat beberapa parameter yang sangat berpengaruh lainnya seperti $\mathrm{pH}$, suhu, kekeruhan air, dan kadar oksigen terlarut (dissolve oxygen). Banyaknya angka kematian ikan pada proses budidaya ikan pembenihan maupun pembesaran disebabkan oleh faktor-faktor tersebut. Penelitian yang telah dilakukan sebelumnya adalah dengan cara memonitor kondisi kualitas air dengan menggunakan satu atau dua sensor saja, misal pH dan Suhu. Sedangkan beberapa parameter lainnya seharusnya juga menjadi pertimbangan seperti kekeruhan air, dan oksigen terlarut agar pertumbuhan ikan menjadi lebih baik. Oleh karena itu perlu dirancang suatu metode yang dapat memonitor kondisi air secara heuristik sekaligus memberikan peringatan apabila terdapat suatu kondisi air yang tidak normal atau tidak semestinya. Pada penelitian ini dirancang suatu sistem yang dapat memonitor kualitas air dengan berbasis mikrokontroler Arduino. Alat ini dapat mengukur beberapa parameter sekaligus yaitu $\mathrm{pH}$, suhu, kekeruhan air, salinitas dan kadar oksigen terlarut. Jika ada parameter yang tidak normal, maka alarm akan aktif. Sistem ini menggunakan data logger untuk melihat datadata dari sensor yang terpasang yang dapat digunakan untuk pengamatan lebih lanjut. Penelitian ini diharapkan dapat meminimalkan angka kematian ikan budidaya air tawar sehingga produksi ikan meningkat dan tercipta ketahanan pangan masyarakat yang baik.
\end{abstract}

Kata Kunci :

monitoring kualitas air, Arduino, $\mathrm{pH}$, suhu, dissolve oxygen.

\begin{abstract}
The abundance of water resources in Indonesia can be utilized as freshwater fish farming. However, the wealth of water resources is sometimes not maintained by humans, so that the quality of water used for fish farming is not good or even below standard. For example, waste pollution that often occurs today can not only attack urban areas but also villages such as household waste. In addition, the change of the rainy and dry seasons, and other factors such as disaster can also cause changes in water quality. Water quality parameters are not only measured in terms of chemical content pollution, but there are some other very influential parameters such as pH, temperature, water turbidity, and dissolved oxygen levels. Many fish mortality in the process of hatchery or enlargement is caused by these factors. Previous research has been carried out by monitoring water quality conditions using only one or two sensors, such as $\mathrm{pH}$ and temperature. While several other parameters should also be considered such as water turbidity and dissolved oxygen so that fish growth will be better. Therefore it is necessary to design a method that can monitor water conditions heuristically while providing a warning if there is an abnormal or improper water condition. In this research, a system that can monitor water quality based on an Arduino microcontroller is designed. This tool can measure several parameters at once, namely $p H$, temperature, turbidity, salinity and dissolved oxygen levels. If there are abnormal parameters, the alarm will be active. This system uses a data logger to view data from the installed sensor that can be used for further observation. This research is expected to minimize the mortality rate of freshwater aquaculture fish so that fish production increases and good community food security is created.
\end{abstract}

Keywords :

monitoring water quality, Arduino, $\mathrm{pH}$, temperature, dissolved oxygen.

\section{Pendahuluan}

Indonesia merupakan salah satu negara yang memiliki kekayaan sumber daya alam air berlimpah diberbagai daerah. Melimpahnya sumber air dapat menjadi peluang usaha bagi masyarakat salah satunya dengan pembudidayaan ikan. Potensi pembudidayaan ikan juga merupakan sektor yang 
sangat menguntungkan baik untuk usaha utama maupun sampingan. Ikan menjadi makanan kegemaran masyarakat Indonesia karena selain harganya murah, ikan juga memiliki kandungan gizi yang tinggi. Ikan memegang peranan penting bagi pemenuhan sumber gizi dan ketahanan pangan masyarakat [1].

Ikan juga berperan dalam dunia kesehatan, misalnya dengan membudidayakan jenis ikan gabus (Channa striata) maka ikan tersebut dapat digunakan sebagai bahan baku serum Albumin atau Nutraseutikal berbasis Fish Serum Albumin (FSA). Penelitian lebih lanjut diyakini bahwa ikan Gurame juga memiliki konsentrasi FSA tertinggi dibandingkan dengan ikan Gabus. Tidak hanya itu, beberapa ikan tawar seperti Lele, Mas, Nila, Tawes, Sidat, Belida, dan Patin juga memiliki kandungan FSA yang baik [2].

Kemanfaatan ikan sebagai mata pencaharian masyarakat, ketahanan pangan dan kesehatan tidak dapat terlaksana dengan baik jika tidak memenuhi standar pembudidayaan yang baik. Kualitas air merupakan salah satu faktor yang paling mempengaruhi tingkat kesuksesan dari kedua proses ini. Namun terkadang kekayaan sumber daya alam air yang terkandung di negara ini mengalami pencemaran lingkungan. Misalnya pada perkotaan, dengan adanya limbah-limbah pabrik atau penanganan sampah yang kurang baik pada tempat pembuangan akhir sampah (TPA) dapat memicu tercemarnya sumber-sumber air yang terdapat di sekitarnya [3]. Selain itu untuk masyarakat yang tinggal di desa bukan berarti aman dari proses pencemaran, tapi juga dapat mengalami jenis pencemaran limbah rumah tangga seperti pencemaran deterjen. Air yang terkontaminasi deterjen 5\% dapat melumpuhkan benih ikan [4]. Beberapa penelitian terkait monitoring kualitas air berdasarkan nilai $p H$, kekeruhan air, dan suhu telah dilakukan oleh [5] [6] [7]. Namun sensor-sensor yang digunakan belum mengukur parameter kualitas air secara menyeluruh. Dalam pembudidayaan ikan air tawar terutama pada pembenihan ikan, terdapat faktor yang sangat penting lainnya yaitu kadar oksigen terlarut (Dissolved Oxygen). Kadar oksigen terlarut adalah salah satu faktor yang perlu dijaga agar ikan dapat bertahan hidup terutama pada proses pembenihan ikan [8].

Kekeruhan perairan atau yang biasa disebut dengan turbiditas perairan merupakan salah satu faktor yang sangat berpengaruh dalam budidaya ikan. Oleh karena itu bila terjadi kekeruhan maka penetrasi cahaya matahari ke permukaan dan bagian yang lebih dalam tidak berlangsung efektif akibat terhalang oleh zat padat tersuspensi, sehingga fotosintesis tidak berlangsung sempurna, sehingga angka kematian ikan dapat bertambah [9].

Berdasarkan permasalahan pada penelitian sebelumnya bahwa sistem monitoring yang telah ada hanya menggunakan beberapa sensor saja dan parameter kualitas air yang diukur belum lengkap.
Oleh karena itu pada penelitian ini bertujuan untuk memonitoring kualitas air secara heuristik dengan menggunakan sensor yang lebih lengkap agar ikan dapat tumbuh secara maksimal. Monitoring dilakukan dengan menggunakan sensor $p H$, suhu, oksigen terlarut, dan kekeruhan air yang diintegrasikan dengan perangkat Arduino.

\section{Tinjauan Pustaka}

Proses kegiatan pembudidayaan ikan air tawar dikategorikan menjadi dua tahap, yaitu tahapan proses pembibitan dan proses pembesaran. Kualitas air menjadi hal yang sangat penting terhadap kedua proses ini agar pertumbuhan ikan menjadi maksimal. Sehingga perlu adanya sistem monitoring kualitas air pada budidaya ikan tawar [10].

Penelitian terkait monitoring kualitas air telah dilakukan menggunakan parameter suhu, kesadahan, dan salinitas [5]. Sistem ini juga menggunakan web localhost untuk menampilkan hasil pembacaan sensor setiap 20 menit, namun harus terhubung dalam jaringan kabel LAN sehingga belum terkoneksi internet. Data hasil monitoring juga belum bisa didownload sehingga sistem hanya dapat mengamati. Sensor kesadahan yang terdapat pada sistem ini juga masih umum dan belum dibandingan atau dikalibrasikan dengan alat ukur yang standar.

Sedangkan penelitian [6] [7] [11] menggunakan sensor $p H$ dan kekeruhan air untuk mengukur kualitas air. Hasil dari pengujian sistem ini menunjukkan bahwa sistem memberikan hasil nilai dari sensor, sensor $p H$ memberikan hasil jika larutan asam dalam air semakin tinggi maka nilai sensor $p H$ akan semakin menurun, setelah itu sensor kekeruhan memberikan hasil jika semakin keruh air nilai sensor kekeruhan akan semakin tinggi, dan terakhir Hasil nilai dari sensor suhu, semakin panas suhu air maka semakin meningkat pula nilai sensor suhu pada $L C D$. Dari pengujian yang sudah dilakukan apakah sensor berjalan sesuai atau tidak, maka hasilnya mendapatkan nilai sensor yang baik, dan hasil dari pengamatan tersebut disimpulkan bahwa sensor yang dipakai akurat dan telah terkalibrasi.

Penelitian terkait kandungan oksigen terlarut (dissolve oxygen), $\mathrm{pH}$, suhu, ORP (Oxidation Reduction Potential) konduktifitas, TDS (Total Dissolved Solid), dan kekeruhan telah dilakukan, namun sistem ini masih berjalan manual tanpa menggunakan mikrokontroler [8]. Dalam penelitian ini disebutkan beberapa nilai rujukan untuk setiap parameter yang diukur.

Monitoring kualitas air juga dimaksudkan untuk mencegah terjadinya upwelling. Upwelling dapat disebabkan akibat sisa pakan atau biasanya ditemui pada kondisi suhu air permukaan lebih dingin, dan berat jenis meningkat. Ketika berat jenis air di permukaan lebih besar dari air pada lapisan air lebih dalam, air permukaan akan turun mendesak air bagian dalam, dan terjadilah upwelling [12]. Upwelling dapat dicegah dengan menggunakan 
sistem real time monitoring yang terintegrasi dengan sensor suhu, $D O$, dan $p H$. Pada penelitian [13] sistem monitoring real time dibangun dengan menggunakan basis komunikasi wifi $802.11 \mathrm{~g} / \mathrm{n}$ dan GSM (Global System for Mobile Communication). Pada penelitian ini sudah menggunakan struktur penyimpanan database yang dihasilkan dari beberapa tahap transfer data yaitu tahap stasiun pengukuran, stasiun perantara dan stasiun kendali. Penggunaan jaringan wifi adhoc menggunakan antena directional mengakibatkan adanya stasiun perantara sehingga transfer data menjadi kurang efisien. Saat ini jaringan komunikasi antar node berbasis internet juga dapat digunakan sebagai alat transportasi data. Sebagaimana pada penelitian [14] menggunakan WSN (Wireless Sensor Network) berbasis ESP8266 untuk memonitor $\mathrm{pH}$ dan suhu pada air kolam. WSN difungsikan untuk menghubungkan beberapa area kolam menjadi kesatuan informasi yang terintegrasi. Komunikasi ini dapat dilakukan salah satunya dengan menggunakan alat pentransfer data yaitu Zigbee yang terintegrasi pada Arduino [15]. WSN dapat dikombinasikan dengan IoT (Internet of Things) dan data logger dapat diterapkan untuk mengukur kualitas air yang memiliki area luas dan terdapat beberapa kolam/tambak. Sehingga sistem berbasis WSN dan IoT ini dapat digunakan untuk menghubungkan area perikanan yang luas serta membutuhkan komunikasi yang terintegrasi [16]. Selain itu, adapun untuk mengakuisisi dan melihat informasi sensor-sensor yang terpasang dapat juga menggunakan smartphone berbasis koneksi bluetooth, namun jangkauan maksimalnya hanya 10 meter [17], sehingga komunikasi berbasis IoT pada kasus yang memiliki area perikanan luas lebih direkomendasikan. Sedangkan untuk area yang tidak terlalu luas dapat menggunakan konektifitas bluetooth.

Saat ini Arduino, Raspberry pi, dan ESP8266 merupakan mikrokontroler yang paling sering digunakan untuk proses monitoring dan controlling dikarenakan alat ini mudah diprogram dan serta memiliki fitur-fitur penunjang yang dapat diberdayakan hingga menjadi sistem berbasis WSN dan IoT. Berdasarkan penelitian [18], Raspberry pi memiliki keunggulan pada sisi pengembangan IoT karena memiliki fitur yang lebih banyak dibandingkan dengan Arduino dan ESP8266. Bagaimanapun juga Raspberry pi memiliki tambahan layer yaitu operating system yang dapat menyebabkan delay pada sistem. Sehingga Arduino dan ESP8266 cocok digunakan pada lingkungan yang terbatas atau tidak terlalu luas karena harganya yang murah dan respon yang lebih cepat dibandingkan dengan Raspberry pi.

Berdasarkan tinjauan pustaka tersebut, maka tujuan dari penelitian adalah merancang serta mengembangkan suatu sistem pemantauan dan pengendalian kualitas air pada budidaya ikan air tawar pada kolam pada area terbatas. Area terbatas ini sering dijumpai di pedesaan Indonesia sebagai mata pencaharian utama ataupun sampingan masyarakat. Dari penelitian sebelumnya diketahui bahwa penggunaan sensor pada sistem mereka masih belum maksimal, karena hanya mengakuisisi beberapa bahkan sedikit sekali parameter kualitas air yang diukur. Sedangkan pada penelitian ini menggunakan sensor yang lebih banyak lagi, yaitu $p H$, suhu, kekeruhan air, salinitas dan oksigen terlarut. Sedangkan pengamatan data dari sensor akan direkam dengan menggunakan data logger, sehingga dikemudian hari petani ikan dapat menganalisis pertumbuhan ikan mereka berdasarkan parameter-parameter yang telah direkam tersebut.

\section{Metode Penelitian}

Tahapan penelitian ini meliputi beberapa tahap yaitu pendalaman study literature, analisa kebutuhan, pembuatan prototype dan pengujian. Study literature dengan membaca paper pendukung dan buku referensi, analisa kebutuhan dengan cara menginventarisir kebutuhan sistem yang akan dibuat. Pembuatan prototype dengan menghubungkan beberapa perangkat menjadi satu kesatuan. Tahap pengujian dengan menguji sensor-sensor dan menampilkan ke $L C D$. Tabel 1 merupakan spesifikasi sistem pada penelitian ini.

Tabel I. Spesifikasi sistem

\begin{tabular}{|c|l|c|}
\hline No. & \multicolumn{1}{|c|}{ Nama Perangkat } & Jumlah (Unit) \\
\hline 1 & Arduino Mega 2560 & 1 \\
\hline 2 & Sensor Kekeruhan & 1 \\
\hline 3 & Sensor Suhu & 1 \\
\hline 4 & Sensor pH & 1 \\
\hline 5 & LCD Nokia & 1 \\
\hline 6 & Key Pad 4x4 & 1 \\
\hline 7 & Relay & 1 \\
\hline 8 & $\begin{array}{l}\text { Laptop TOSHIBA } \text { i3 } \\
2350 M \text { 2,3 GHz/2 } \\
\text { GB }\end{array}$ & 1 \\
\hline
\end{tabular}

Model skema sistem pemantau kualitas air dapat dilihat pada Gambar 1.

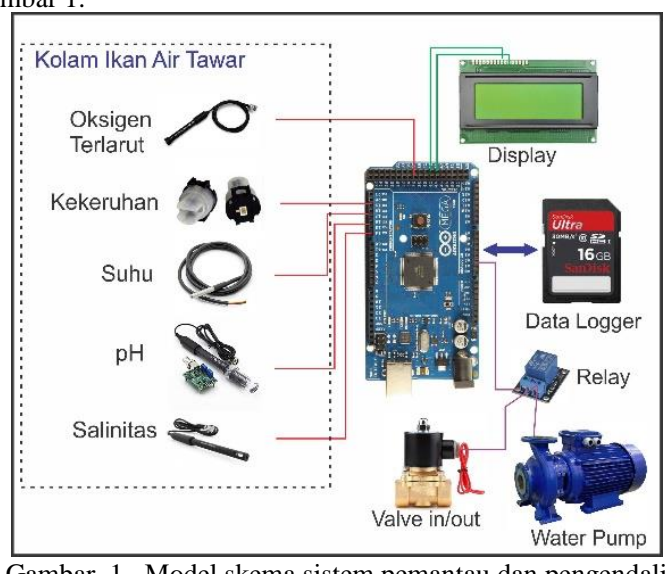

Gambar. 1 Model skema sistem pemantau dan pengendal kualitas air.

Pada gambar 1 merupakan skema usulan pada penelitian kali ini. Pada prinsip kerjanya, sensor suhu, $p H$, kekeruhan, digunakan sebagai input. 
Arduino digunakan sebagai otak pengontrolan sistem, dan akan memberikan keluaran berupa informasi ke LCD Display, dan akan mengaktifkan relay untuk menggerakkan pompa serta valve. Pada gambar 1 terdapat tanda garis merah, pelaksanaan penelitian ini kami fokuskan terlebih dahulu pada gambar yang berada di dalam area yang diberi garis merah.

\section{Hasil dan Pembahasan}

\section{A. Pembuatan prototype}

Pembuatan prototype sistem pemantauan dan pengendalian kualitas air pada budidaya ikan air tawar dengan cara menggabungkan komponen elektronika diantaranya yaitu: Arduino Mega 2560, Real Time Clock (RTC), Modul micro SD, LCD Nokia 5110, Sensor Suhu, Sensor Kekeruhan dan sensor $p H$. Komponen-komponen tersebut disusun sedemikian rupa dengan menggunakan kabel jumper sebagai penghubung antar komponen sehingga menjadi sebuah prototype dan dikemas dalam sebuah box acrylic. Prototype tersebut dapat dilihat seperti pada gambar 2 .

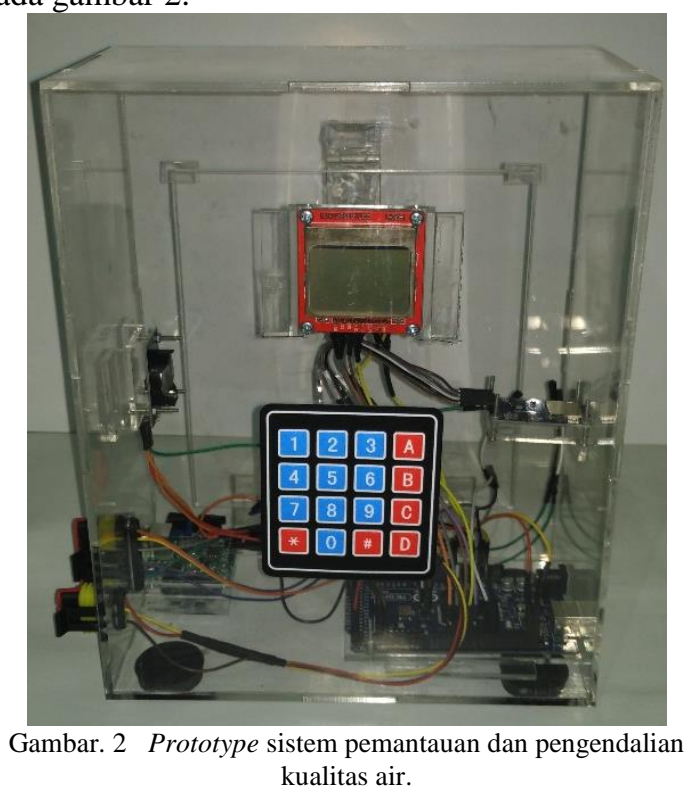

\section{B. Pembuatan Source Code}

Pembuatan source code pada penelitian ini dengan menggunakan software open source Arduino versi 1.8.8. Software Arduino menggunakan Bahasa pemrograman $\mathrm{C} / \mathrm{C}++$ yang sudah sangat familiar dan sering digunakan untuk pembuatan software aplikasi serta tidak diragukan lagi kehandalannya. Selain itu pada software Arduino telah dilengkapi berbagai driver untuk mengintegrasikan board Arduino dengan komputer. Hasil dari pembuatan source code tersebut kemudian disimpan dalam format ino dan di export dalam format hex. Gambar 3 merupakan hasil dari pembuatan source code sistem pemantauan dan pengendalian kualitas air pada budidaya ikan air tawar.

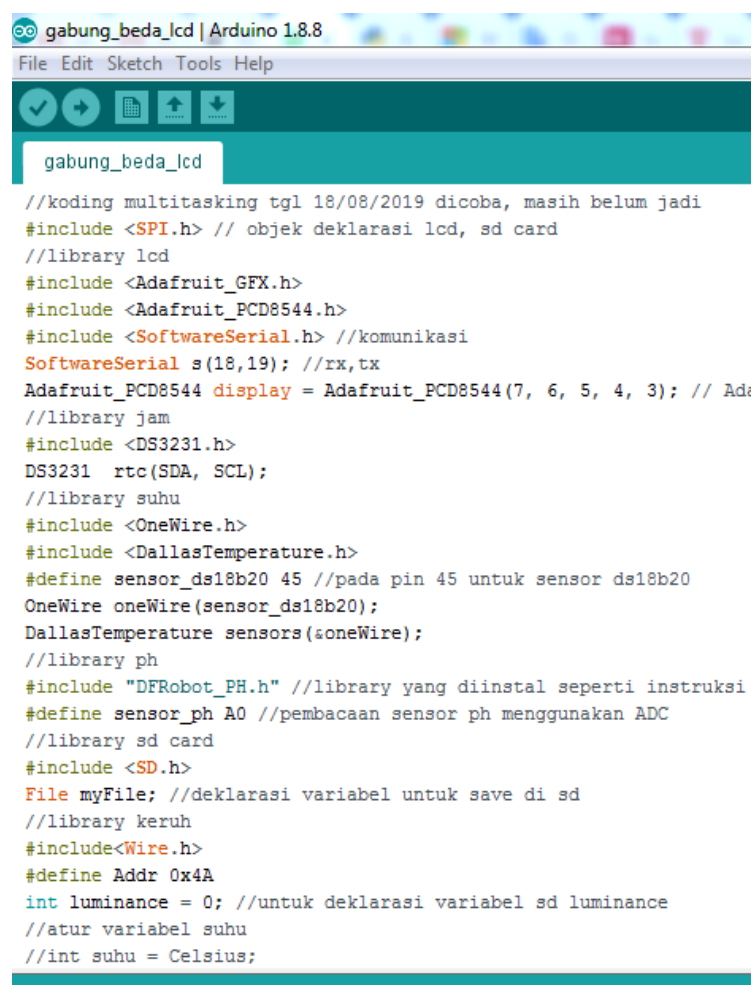

Gambar. 3 Source Code sistem pemantauan dan pengendalian kualitas air.

\section{Pengujian Prototype}

Pengujian prototype pada penelitian ini meliputi pengujian sensor dan tampilan $L C D$. Pengujian sensor itu sendiri antara lain pengujian sensor suhu, sensor kekeruhan dan sensor $p H$. Pengujian ini diharapkan untuk mengetahui apakah sensor bekerja dengan normal dan $L C D$ dapat menampilkan hasil baca sensor tersebut.

Tahap pengujian ini dilakukan dengan menyediakan air sebagai bahan percobaan untuk menguji sensor. Air yang disediakan sebanyak 7 gelas, gelas ke-1 merupakan gelas dengan isi air dingin, gelas ke-2 berisikan air sabun, gelas ke-3 berisikan air biasa, gelas ke-4 berisikan air cuka, gelas ke- 5 berisikan air kopi panas, gelas ke-6 berisi air teh dan gelas ke-7 berisi air susu. Gambar 4 merupakan air uji sensor yang terdiri dari 7 gelas dengan isi yang berbeda.

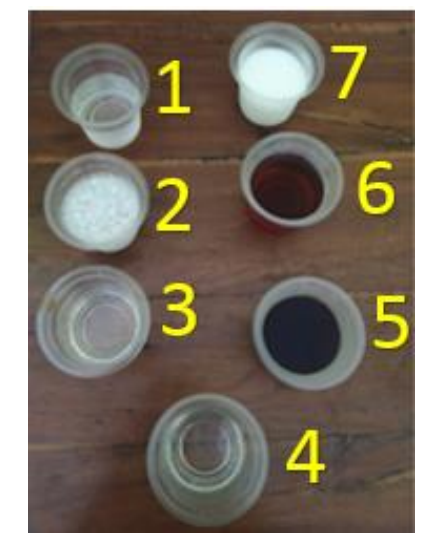

Gambar. 4 Air untuk pengujian sensor. 
Pengujian sensor yang pertama dengan menguji sensor suhu. Type sensor suhu yang digunakan yaitu type $D S 18 B 20$. Sensor ini bekerja pada temperatur antara $-55^{\circ} \mathrm{C}$ sampai $+125^{\circ} \mathrm{C}$. Pengujian sensor ini dilakukan dengan menggunakan air panas seperti pada air gelas ke-5 yang berisi air kopi panas, air biasa seperti pada gelas ke-3 dan air dingin seperti pada gelas ke-1. Pengujian ini dilakukan dengan mencelupkan sensor ke gelas secara bergantian. Gambar 5 merupakan hasil uji sensor suhu dengan air panas, dan $L C D$ menunjukan hasil baca sensor adalah 46,25 ${ }^{\circ} \mathrm{C}$. Gambar 6 menunjukan hasil uji sensor suhu dengan air biasa, hasil pembacaan suhu pada $L C D$ adalah $26,25{ }^{\circ} \mathrm{C}$. Gambar 7 menunjukan hasil uji sensor suhu dengan air dingin, hasil pembacaan suhu pada $L C D$ adalah $7,38^{\circ} \mathrm{C}$.
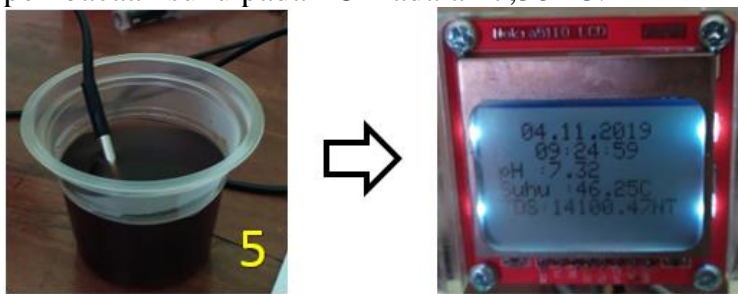

Gambar. 5 Hasil uji sensor suhu dengan air panas.

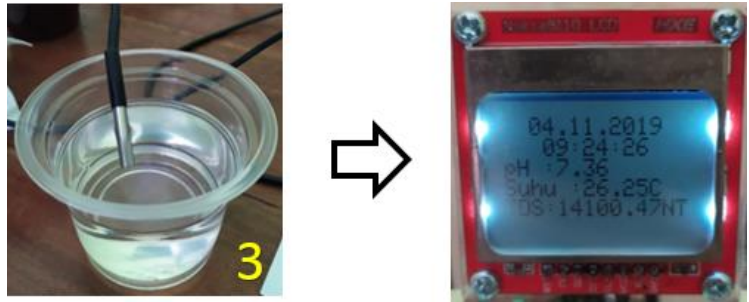

Gambar. 6 Hasil uji sensor suhu dengan air biasa.

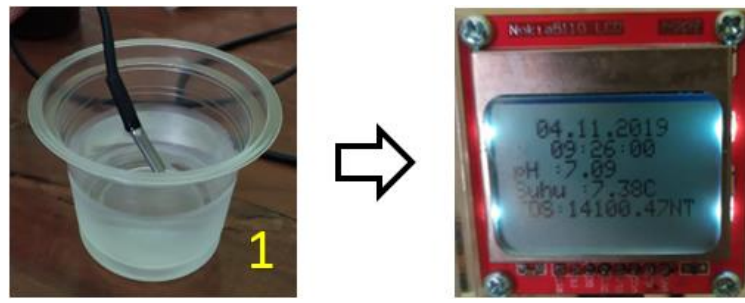

Gambar. 7 Hasil uji sensor suhu dengan air dingin.

Pengujian sensor yang kedua dengan menguji sensor $p H$. Type sensor $p H$ yang digunakan yaitu type MSP340. Sensor ini bekerja pada $p H$ antara 0 - 14 . Pengujian sensor ini dengan menggunakan air sabun seperti pada gelas ke-2, air biasa seperti gelas ke-3 dan air cuka seperti gelas ke-4. Gambar 8 adalah hasil uji sensor $p H$ dengan air sabun dan hasil pembacaan pada $L C D$ yaitu 11,11 . Gambar 9 adalah hasil uji sensor $p H$ dengan menggunakan air biasa dan hasil pembacaan pada $L C D$ yaitu 6,97 . Gambar 10 merupakan hasil uji sensor $p H$ dengan menggunakan air cuka dan hasil pembacaan pada $L C D$ yaitu 4,37 .
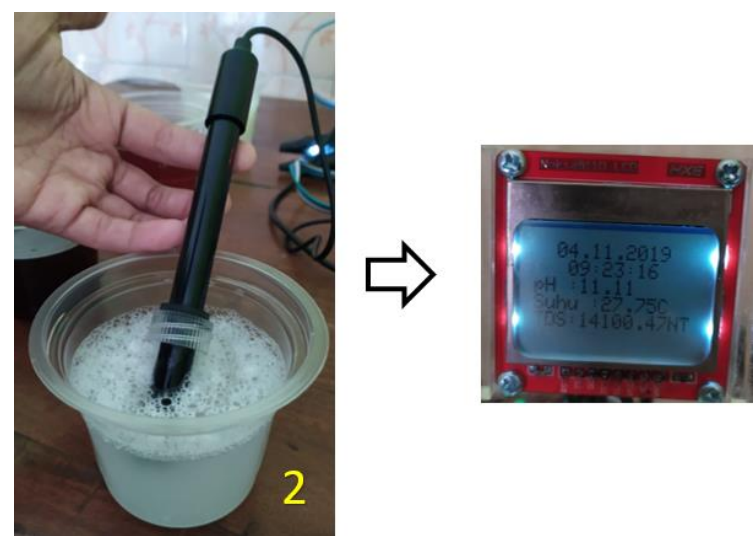

Gambar. 8 Hasil uji sensor $p H$ dengan air sabun.
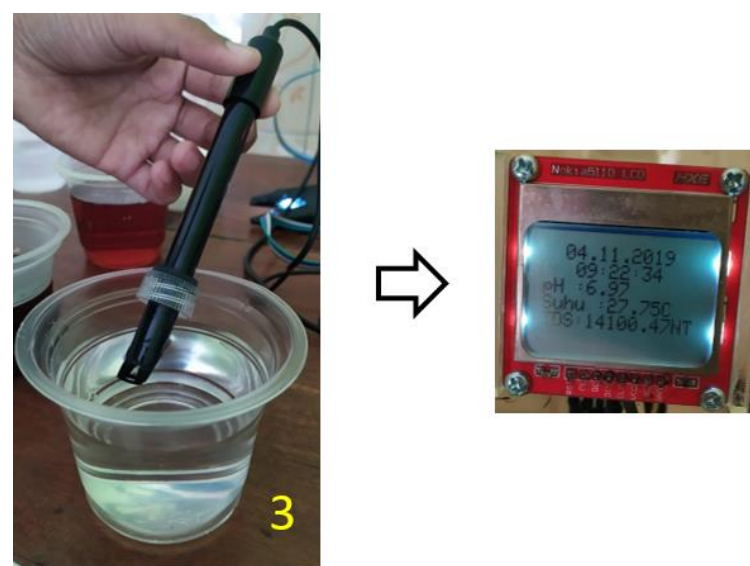

Gambar. 9 Hasil uji sensor $p H$ dengan air biasa.
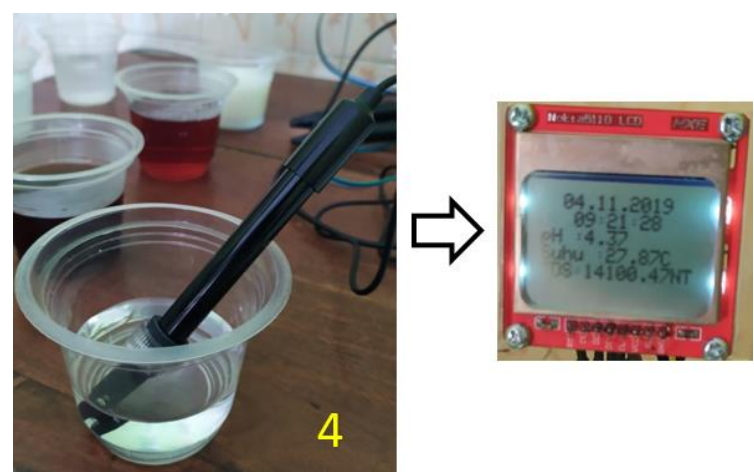

Gambar. 10 Hasil uji sensor $p H$ dengan air cuka.

Pengujian sensor yang ketiga dengan menguji sensor kekeruhan. Sensor kekeruhan ini dibuat sendiri dengan prinsip penerimaan cahaya (Lux Meter GY49 MAX44009 Ambient Light) dengan memodifikasi menjadi sensor kekeruhan. Pengujian sensor ini dengan menggunakan air kopi seperti pada gelas ke5 , air teh seperti gelas ke-6 dan air susu seperti gelas ke-7. Gambar 11 merupakan hasil pengujian sensor kekeruhan dengan menguji pada air kopi, hasil pengukuran pada tampilan $L C D$ yaitu 8617,95 Nephelometric Turbidity Unit (NTU). Gambar 12 merupakan hasil pengujian sensor kekeruhan dengan menguji pada air teh, hasil pengukuran pada tampilan $L C D$ yaitu 125333,75 NTU. Gambar 13 merupakan hasil pengujian sensor kekeruhan dengan menguji pada air susu, hasil pengukuran pada tampilan LCD yaitu 5483,52 NTU. Gambar 14 
merupakan hasil pengujian sensor kekeruhan dengan menguji pada air biasa, hasil pengukuran pada tampilan $L C D$ yaitu 15667,19 NTU.
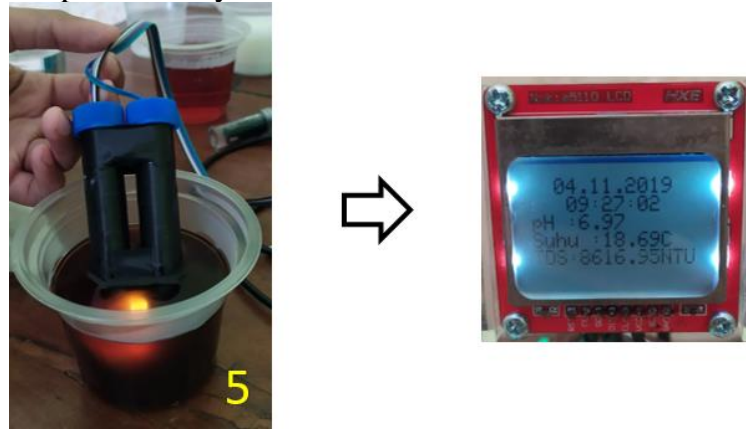

\section{5}

Gambar. 11 Hasil uji sensor kekeruhan dengan air kopi.
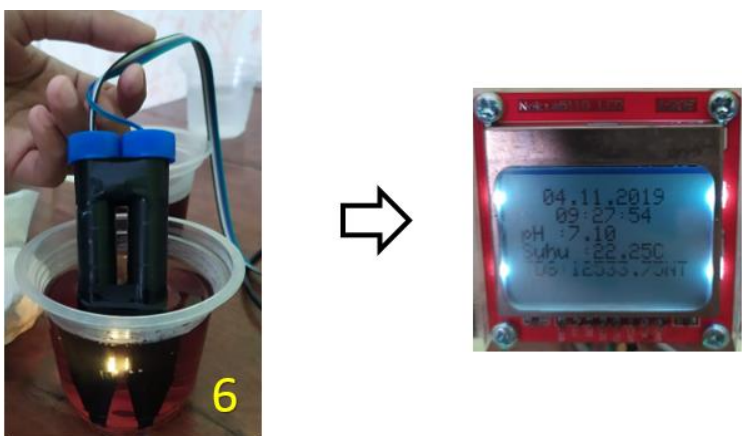

Gambar. 12 Hasil uji sensor kekeruhan dengan air teh.
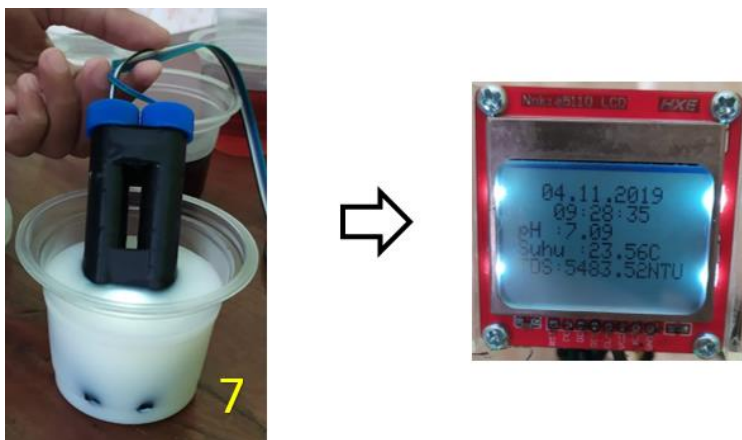

Gambar. 13 Hasil uji sensor kekeruhan dengan air susu.
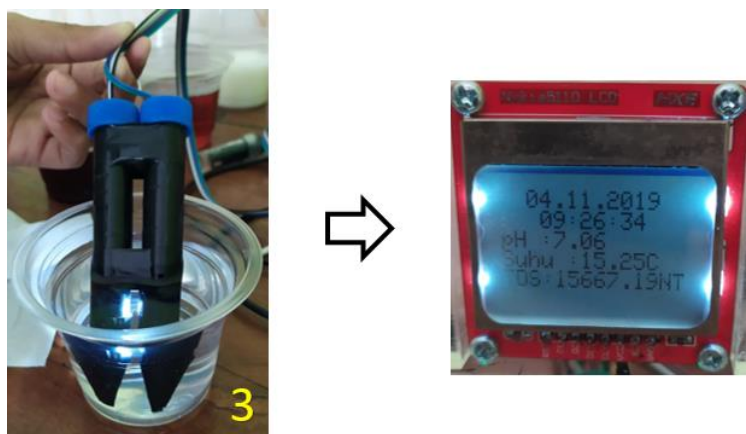

Gambar. 14 Hasil uji sensor kekeruhan dengan air biasa.

\section{Kesimpulan dan Saran}

Prototype sistem pemantauan dan pengendalian kualitas air berhasil dibuat dan sensor bekerja normal pada saat dilakukan pengujian yang tampilan oleh $L C D$. Prototype yang dibuat bisa digunakan untuk memantau secara real time.

\section{Ucapan Terimakasih}

Penulis mengucapkan terima kasih kepada Universitas Amikom Purwokerto yang telah memberi dukungan pendanaan Penelitian Dosen Muda Amikom Pendanaan Tahun 2019.

\section{Daftar Pustaka}

1] Hafiludin, "the Analysis of Nutritional Content of Milkfishes Which Come From Different," J. Kelaut., vol. 8, no. 1, pp. 37-43, 2015.

[2] R. Susilowati, H. I. Januar, D. Fithriani, and E. Chasanah, "Potensi Ikan Air Tawar Budidaya Sebagai Bahan Baku Produk Nutraseutikal Berbasis Serum Albumin Ikan," JPB Kelaut. dan Perikan., vol. 10, no. 1, pp. 37-44, 2015.

[3] N. Susila, "Dampak Pencemaran Air Sungai Kahayan pada Usaha Budidaya Ikan Karamba di Kelurahan Pahandut Seberang Kota Palangka Raya,” J. Ilmu Hewani Trop., vol. 4, no. 2, pp. 71-74, 2015.

[4] F. D. Wulansari and Ardiansyah, "Pengaruh Detergen terhadap Mortalitas Benih Ikan Patin Sebagai Bahan Pembelajaran Kimia Lingkungan,” J. EduSains, vol. 1, no. 2, pp. 120, 2013.

[5] E. D. Agustiningsih, "Perancangan Perangkat Monitoring Kualitas Air Pada Kolam Budidaya,” J. Umr., pp. 1-15, 2016.

[6] A. F. Machzar, S. R. Akbar, and H. Fitriah, "Implementasi Sistem Monitoring Kualitas Air Pada Budidaya Tambak Udang dan Bandeng," J. Pengemb. Teknol. Inf. dan Ilmu Komput., vol. 2, no. 10, pp. 3458-3465, 2018.

[7] I. Prasetya, D. Wibawa, F. T. Elektro, U. Telkom, and L. Fuzzy, "Rancang Bangun Sistem Pendeteksi Kualitas Air Menggunakan Metode Fuzzy Logic Universitas Telkom," eProceeding Eng., vol. 3, no. 2, pp. 1321-1326, 2016.

[8] L. Riadhi, M. Rivai, and F. Budiman, "Dampak Kualitas Air Pada Budi Daya Ikan Dengan Jaring Tancap Di Desa Toulimembet Danau Tondano," J. Budid. Perair., vol. 3, no. 2, pp. 5-9, 2015.

[9] M. R. Maturbongs, "PENGARUH TINGKAT KEKERUHAN PERAIRAN TERHADAP KOMPOSISI SPESIES MAKRO ALGAE KAITANNYA DENGAN PROSES UPWELLING PADA PERAIRAN RUTONGLEAHARI," Agricola, vol. 5, no. 1, pp. 21-31, 2015.

[10] I. Syofyan, dan Polaris Nasution, and D. Fakultas Perikanan dan Ilmu Kelautan Universitas Riau, "Studi Kualitas Air Untuk Kesehatan Ikan Dalam Budidaya Perikanan Pada Aliran Sungai Kampar Kiri,” J. Perikan. dan Kelaut., vol. 161, no. April, pp. 64-70, 2011 . 
[11] A. Lintang, F. Firdaus, and I. Nurcahyani, "SISTEM MONITORING KUALITAS AIR PADA KOLAM IKAN BERBASIS WIRELESS SENSOR NETWORK MENGGUNAKAN KOMUNIKASI ZIGBEE," in SNAIF, 2017, pp. 145-152.

[12] N. A. Swastika, S. Prabowo, and B. Erfianto, "Upwelling Solution Prototype Using Wireless Sensor Network," Int. J. Inf. Commun. Technol., vol. 2, no. 2, p. 37, 2017.

[13] Y. Y. Maulana, D. Mahmudin, R. I. Wijaya, and G. Wiranto, "Monitoring Kualitas Air Secara Real-Time Terintegrasi," J. Elektron. dan Telekomun., vol. 15, no. 1, pp. 23-27, 2016.

[14] U. Syafiqoh and A. Yudhana, "Pengembangan Wireless Sensor Network Berbasis Internet of Things untuk Sistem Pemantauan Kualitas Air dan Tanah Pertanian," J. Inform. J. Pengemb. IT, vol. 3, no. 02, pp. 285-289, 2018.
[15] S. Soijoyo and A. Ashari, "Analysis of Zigbee Data Transmission on Wireless Sensor Network Topology," Int. J. Adv. Comput. Sci. Appl., vol. 8, no. 9, pp. 145-151, 2017.

[16] Y. Y. Maulana, G. Wiranto, and D. Kurniawan, "Online Monitoring Kualitas Air pada Budidaya Udang Berbasis WSN dan IoT Online Water Quality Monitoring In Shrimp Aquaculture Based On WSN and IoT," Inkom, vol. 10, no. 2, pp. 81-86, 2016.

[17] Y. M. Sambora, "Monitoring Kualitas Air Pada Budidaya Udang Berbasis Atmega328 Yang Terkonfigurasi Bluetooth Hc-05," E-Jurnal Prodi Tek. Elektron., no. 13507134029, 2016.

[18] P. R.Dinkir, Patnaik, "A Comparative Study of Arduino, Raspberry Pi and ESP8266 as IoT Development Board," Int. J. Adv. Res. Comput. Sci., vol. 8, no. 5, pp. 2350-2352, 2017. 